\title{
THE ART OF TEACHING MORALS THROUGH THE SHORT STORIES WITH REFERENCE TO RUSKIN BOND'S SELECT SHORT STORIES
}

\author{
REVATHY. $M^{1} \&$ ARUNA ARPUTHAMALAR. $\mathrm{P}^{\mathbf{2}}$ \\ ${ }^{I}$ Research Scholar, Department of English, Vel Tech Rangarajan Dr. Sagunthala R\&D Institute of Science and Technology, \\ Avadi, Chennai, India \\ ${ }^{2}$ Assistant Professor, Vel Tech Rangarajan Dr. Sagunthala R\&D Institute of Science and Technology, Avadi, Chennai, India
}

ABSTRACT
Ruskin Bond is one of the most prominent short story writers in Indian writing in English who is proficient in connection
with children's literature, Ecocriticism, and writing for adults. There are plenty of ways to teach moral values. Especially,
short stories nourish the readers to grasp the content quickly and stock it for further. Bond teaches moral values to
children through short stories in an interesting manner. The reality lies in the short stories help the children to connect it
with their daily lives. This paper covers the art of teaching moral values with reference to Ruskin Bond's select short
stories The Blue Umbrella, The Thief, and Untouchable.
KEYWORDS: Moral Values, Teaching, Reality, Short Stories

Received: Apr 15, 2020; Accepted: May 06, 2020; Published: Jun 30, 2020; Paper Id.: IJMPERDJUN2020266

\section{INTRODUCTION}

Ruskin Bond is a well-known writer who uses splendid language to describe the emotions of a human. He was born in Kasauli on19th may 1934 studied in a boarding school at Musssourie. His parents got separated and his mother remarried a Punjabi. He was under the care of his father until his father's death. The moments he spent with his father gave soul to many of his stories. The Room on the Roof is the first novel of Bond that motivated him to follow his dream of becoming a writer. He has won many awards and prizes for his literary achievements such as John Llewellyn Rhys Prize, Sahitya Akademi Award, Padma Shri and Lifetime Achievement award. His passion for writing, subjectivity towards life, focused frame of mind equipped with a reflection of the loss of parental care, a quest for identity, longing for affection and care shaped him an honest idol of reality. Instead of telling fairy tales and myths to children, the importance of knowing the existent world earns value in his stories. The influence of Dickens, Hugh Walpole, Kipling, Jack London, and Maugham can be seen in the trait of wielding subjectivity.

\section{DISCUSSIONS}

Age-old traditions had possessed the art of story-telling and it served manifold function at the same time. Lot of difficulties in building interest among children to develop their reading habit, the art of choosing simple and familiar vocabularies, story structure, identical characters, visual language and unique perspective is on the head of the writer. Unlike adults, less attention to written stories is given by children. Teaching them moral and social values through stories is a difficult task to appeal. Growing up reading the fairy tales lead children to believe imaginative characters and unrealistic expectations. According to Jungian interpretation, the world of fairy tales designs a stage of assumption where children are convinced of a perfect life force with the slogan on it "happily 
ever after" motivating the children to have a positive point of view. Trust on positive things to happen alone guides to have despaired when it comes to face troublesome moments. The balanced state of mind manages to experience the positive and negative side of life that causes children to accept reality. Approaching a serious issue would give dissatisfaction while setting them up in a superficial way but the stories of reality do the honors for children to know about the factual crisis.

In the present scenario, the production of children's books has been entailed for teaching moral and ethical values. Ruskin Bond stories are transcribed according to the necessity of the present core. Presenting the autobiographical elements as the basement for writing stories, accord the essence of reading a real-time story. Like R.K Narayan's Malgudi, Bond's background of the stories is Mussoorie or Garhwal, chosen preferring a certain circumstance. Generally, Bond starts narrating a story with a sketch of the main character. The Blue Umbrella begins thus;

"Neelu!Neelu! Cried Binya. She scrambled barefoot over the rocks, ran over the short summer grass up and over the brow of the hill, all the time calling Neelu".

Right from the beginning, the characterization of Binya and Ram Bharosa are contrasted. Binya is a hilly girl aged eleven who is happy in the company of inhabitants and nature. She likes being on her own rather than accompanying someone, holding responsibility on her family, she helps her mother along with her elder brother Bijju in her daily chores. She learned to be independent after losing her father in her second year of birth. When she roams around the forest, it happens to fall in love with a blue umbrella that the tourists bought from their native. Being an extremely reticent girl, she hesitates to reveal her desire towards the blue umbrella. The Tourists have seen her, they are not familiar with a village girl so calls her. Before expressing her admiration, tourist's interest in her claw hanging pendant prepares her to express the fond for the umbrella. Getting the umbrella after the pendant, she carries it as it is a precious thing wherever she goes. The way she cares for the umbrella and the colour of it attracts the villagers to fall for it.

On the other hand, Old Ram Bharosa, the man who runs a tea stall in the village is enticed by the Umbrella. He performs cheesy tricks to own it; the arrogance of snatching umbrella from a little girl lead him suffered the tortures of greed and the despair of loneliness. People stopped coming to his shop after knowing the real shade of him, losing all the dignity among the villagers and left alone. He is accused of selling his soul for a blue umbrella. The pity Binya senses somehow responsible for his state of misery. Knowing the sequence that the Old Ram Bharosa underwent, Binya purposefully keeps her umbrella at his shop to make the dark line between them fade away. Sacrificing the most admired thing changes the heart and mind of Ram Bharosa and gets quiet diffident for being so incapable. She is awarded a bear claw pendant by the Ram Bharosa considering her nature of understanding others melancholy. By the end of the story, villagers find readiness to forgive Bharosa because of Binya and her effort to project him positively.

As usual, Bond's protagonist reminiscences the positive influence, the act of sacrificing the umbrella to change the Ram Bharosa a better person made him feel the essence of sharing and being loved. The child characters of Ruskin Bond direct the readers to take responsibility. Human faces different lifestyle by birth, the situation and circumstances differ from person to person some learn to occupy more than enough and some learn to share what they have. Here, the complication comes to Binya to choose either winning the heart of Ram Bharosa or being achieved the target by defeating him. Binya modifies the goal factor to get something better like getting Ram Bharosa changed as a good man than keeping the umbrella for long. 
The element of portraying the characteristics of common people in his stories seeing that majority of people belongs to the common community of human concern. In short, the factual events and truth have stocked in his technique, never ignored to respect the tradition but he follows a modern way of writing and projecting the ideas.

Similarly, The Thief emphasis the idea of forgetting and forgiving to restart a new virtuous life. We never know what the real name of the protagonist is but creating an image through characterization is possible. The story is about a thief in the town where the contrary character Arun lives. Arun and the thief are from the same age more or less but different perspectives of life, the former has the life with full of honesty beyond poverty and the latter enjoys living the life by stealing everyone's money. Intending to steal his money, the thief starts a conversation with Arun and demands for a job to be with him finding the right moment to get his money stolen. Unaware of the motive, after such hesitation Arun offers a cooking job to him who introduced himself as Deepak because he does not have money to spare for a cook. Up to the request of feeding every day is enough, Arun takes Deepak to his home. The food, Deepak cooked on the very first day was eaten by the cat outside brings Arun to know that Deepak does not know to cook. Knowing the lies he had told, Arun teaches him to write simple words every day assuring to teach how to write a whole sentence. While purchasing items for cooking, Deepak made a profit of 25 paise a day thinking that he is not getting a salary for his work. Arun may be aware of it but never expressed anything about it both will go out and enjoy if Arun gets more money from his work. Once Arun is paid 100 rupees as his salary, returning to the home he kept it under the pillow. When Deepak comes to have a look at it, he plans to run away taking the money that culminated him to be gone with that. The innocent eyes and caring attitude of Arun dig the gratitude in Deepak and the vision of forthcoming isolated days alert him to return to Arun. Facing many difficulties to keep the money as it was, Deepak places it and pretends nothing happened to Arun. The next day morning, there is five rupees note between Arun's fingers saying that he made money yesterday and able to pay him regularly now onwards. The rupee note is still wet because of yesterday's rain, Deepak can understand that Arun is aware of the incident that happened yesterday. Instead of punishing him, Arun wanted to teach him so he keeps quite to change him in a good way. The soft nature and unexpected love of Arun towards the thief change him a better man.

The speechless characters of Bond stand for love and care to ignore arrogance, the act of showering affection is revealed in the behaviour and attitude of them. The lengthy dialogues and forceful course are not given importance here. They are adapted to accept the people with their faults simulating the good inner-self to overcome the polished adverse. The final heart touching dialogues of the story portrays the benignity of mankind:

"He knew; but neither his lips nor his eyes said anything about their knowing.

I smiled at Arun in my most appealing way; and the smile came by itself without my knowing it”.

Bond's stories sprinkled with autobiographical elements that engage the readers reading as one's story. The purpose of coating events in colour of the autobiographical component is to communicate the personal point about life. Bond finds the writing is a unique way to communicate with people creating awareness of natural resources and all the fundamentals needed for life. Reality lies here, the words of Bond are from his heart and experience not for the sake of writing. Often he uses animal images in his works like 'All creatures are great and small' to make known the values of them and teaches the way to protect them. The beginning quote influenced the importance of inhabitants greatly:

"Instead of having brothers and sisters to grow up with in India, I had my companions an odd assortment of pets, which included a monkey, a tortoise, a python and a Great Indian Hornbill” 
It is a great time to remind the people to leave all the natural resources that we have now to the forthcoming generation. Fundamental elements for a living are given parallel importance as same as the story plot in these stories.

Most of his characters in short stories do not have names but the title 'Grandfather' or 'Grandmother' to recognize at every house. The act of moral learning from grandparents would be a unique way to celebrate; comparatively the stories have a bunch of life experiences to share with love. Good stories are those with morals that can be applied to reality and our grandparents are full of wisdom just waiting to be dispersed.

The story Untouchable puts light on the social division in India. The protagonist is alone in his home due to the health issue of his father. He used to be accompanied by his father since his childhood as the Children in the neighbourhood do not like to play with him. So, he is left alone after his father's admission to a hospital. There is a sweeper boy in the house accompanied to help him doing house works, his main job is to sprinkle water around the window to keep the room cool. The description of his appearance is a bared upper body with white teeth, naked feet, and extremely black in colour. Every time he sees the protagonist, the boy tenderly laughs at him. Being the son of Sahib, Ruskin is not allowed to mingle with the kids of the working class. Ruskin is afraid of darkness when staying alone. Seeing a centipede near the window, he screams of fear and jumps on his bed, on hearing the screaming of Ruskin the sweeper boy came instantly killed the centipede and left his room with the same smile on his face. Soon after, the wind outside becomes heavy and fierce, the situation becomes horrible. Helpless to be alone, he runs away to the sweeper boy room and seated aside. The sweeper boy tells that the monsoon started and they smile at each other. The world of same-age children is contrasted, the sweeper boy cannot study at school and Ruskin need not work at home. Therefore the contrasted lifestyle of two children has shown here, the protagonist lives in the polished side of life and the sweeper boy stands for serving people around him. Strong discrimination and social divisions are involved in this story that memoirs the violence of caste system

The genre of these stories is different from one another but expresses strong humanity. Gratitude and regret are the themes of all these stories. The moral simply knows the right path to see and do things. The motive of moral stories is to teach lessons that of standards of behaviour, principles of right and wrong and motivates the reader to be a better person. To the present condition, the writers are in the compulsion to present a reality-based story that should be helpful for the children and adults in their life.

Teaching morals for adults and children would get the country healthy in all its sources, the lack of grandparents' tales for grandchildren is rectified through the moral stories based on the reality of Bond. External appearance gets less importance in these stories, the description may give a hint to feel the character exactly since the character, behaviour, attitude and good-hearted are worth rather than being attractive. The children and adults protagonists of Bond leading the reader to grasp their own story or the story of people next door. Ruskin Bond takes the responsibility of teaching major issues in a mild way, such as discrimination, social issues, Ecocriticism and the importance of inhabitants. The most seen slogan of his stories is 'Earth is common for all', we are the one who occupied the space of flora and fauna. As per the formulation of Earth, Species depend on one another which cannot live without the help of others and destroying something makes others disturbed. The life cycle of species depend on one another, and the help must be taken from other species to turn on the cycle. Feeding the value of natural resources and moral values through story telling is a unique form of teaching kids and adults. 


\section{CONCLUSIONS}

Children have a marvellous attitude to learn values when activities are curious and entertaining to them. Stories are an optimal tool to use in learning the moral values as they are interesting to listen with mind and soul. Moral stories make learning more delightful and refreshing to children. What we see here, is that it is important to teach the children why we should do the right things rather than teaching them what is right and what is wrong. When the stories help children to connect it with their own experience, it would be useful for them to learn and live following moral values. The autobiographical elements in Bond stories help children to experience the real-time incidents that act as an example in their life. Bond's stories are capable of making the readers raise voice for good or against bad character. Good characters speak through their healthy characteristics where else bad characters are given chances to transform into a positive mindset. Thus research explained the readers to utilize the real-life experience of Bond given in these stories as an example. The development happens naturally on the moral and ethical values when readers engaged in the stories. Based on what they do and hear after reading the stories, they can relate the values in their life. The conventional way of storytelling starts with "once there was" and ends with "the moral of the story is" get less importance compared with the present scenario. As Bond could mingle with the current stream, he presents the stories which are fruitful to people of present formation and these stories cooperate to clear the dilemmas in learning moral values. The motif of these stories is to know that there is none to call ever bad or ever good, all is the situation that changes people, transforming the positive ideas and good thoughts in mind while getting chance is a must.

\section{REFERENCES}

1. Bond, Ruskin. The Kitemaker stories. Penguin Books Ltd, 2011, pp. 23-27.

2. Bond, Ruskin. The Blue umbrella. Rupa Publications India Pvt Ltd, 1992.

3. Bond, Ruskin. The Night Train at Deoli. Penguin Books Ltd, 1988, pp. 38-43.

4. Bond, Ruskin. Rusty the Boy from the Hills. Penguin Books Ltd, 2003, pp. 1-20.

5. Jhala, Parikshit. A study of morality teachings and gaiety in khushwantsingh's works. Veda's Journal of English Language and Literature, Vol. 4, No. 4, June 2017, pp. 38-4.

6. Betts, John. Jungian Fairy Tale Interpretation. Jungian Psychoanalysis, Jungian.ca, http://jungian.ca/fairy-taleinterpretation/, 24/4/2020.

7. Das, Saptorshi, and Isa Mishra. "The Role of Nature in Creating Mystery and Terror in the Short Stories of Ruskin Bond, with Special Reference to Listen to the Wind and the Wind on Haunted Hill. "International Journal of English and Literature (IJEL) 8. 4, Aug 2018, 15-20

8. Kumaraswamy, Ravipati. "Stream of Consciousness, the Techniques of Shashi Deshpande."International Journal of English and Literature (IJEL) 8. 1, Feb 2018, 85-88 

